\title{
CATEGORIZATION OF LEAN SIX SIGMA TOOLS AND TECHNIQUES BASED ON DMAIC FRAMEWORK
}

\author{
Norshazwana Akmal Hanafi ${ }^{1}$ \\ Faculty of Management, \\ Universiti Teknologi Malaysia (UTM), Malaysia \\ (Email: shazwanahanafi@gmail.com) \\ Tan Owe Kowang ${ }^{2}$ \\ Faculty of Management, \\ Universiti Teknologi Malaysia (UTM), Malaysia \\ (Email: oktan@utm.my) \\ Goh Chin $\mathrm{Fei}^{3}$ \\ Faculty of Management, \\ Universiti Teknologi Malaysia (UTM), Malaysia \\ (Email: gcfei@utm.my)
}

Accepted date: 03-12-2017

Published date: 09-07-2019

To cite this document: Hanafi, N. A., Tan, O. K., \& Goh, C. G. (2019). Categorization of Lean Six Sigma Tools and Techniques Based on DMAIC Framework. Journal of Information System and Technology Management, 4(13), 01-12.

DOI: $10.35631 / J I S T M .413001$

\begin{abstract}
Lean Six Sigma is like twins to continuous improvement project which can be managed by using DMAIC methodology. DMAIC methodologies consist of several tools and techniques, and these tools differ for different industries. Thus, this study seeks to explore and compare the experiences of various organizations from various industries undertaking DMAIC activities within their organization in order to sustain the performance and maximize their value. This paper provides an overview of each tools and techniques used in DMAIC stage.
\end{abstract}

Keywords: Lean Six Sigma, DMAIC, Lean Management, Six Sigma

\section{Introduction}

Nowadays, most organizations attempt to implement Lean Six Sigma concept in their business, ranging from manufacturing, service or even on public sector. Lean Six Sigma is like twins to continuous improvement project which can be managed by using DMAIC methodology. Based on previous study, there are more than hundreds of tools used in this DMAIC stage, and the tools used are differ for different industries. Prior study discusses these tools separately and most of the study view DMAIC as a single set for each industry. Thus, this study seeks to explore the experiences of various organizations from various industries undertaking DMAIC activities within their organization in order to sustain the performance 
and maximize their value. This paper provides an overview and comparison of each tools and techniques used in DMAIC stage for 6 industries.

\section{Overview of Lean Concept}

Lean is an operational philosophy focuses on a business' internal needs with the ultimate aim to maximize value added activities by identifying and eliminating waste in an organization. This concept originated from Toyota Motor Corporation in early seventies and focused on reducing cycle time and waste in processes (Frank, H.James, Chuck, \& Rich, 2014; Sandra, 2009b). Besides, lean is not only focusing on cost reduction while improving quality, but also serves as guidance for organization to achieve tremendous growth (Sisson \& Elshennawy, 2015).

The basic fundamental of Lean concept is the ability to identify waste in the organization as waste identification and elimination is one of the ways to increase profit. Waste is typically defined as any activity that customer is not willing to pay for. Traditionally in 1988, Taiichi Ohno has classified waste into seven major categories which are overproduction, waiting, transportation, inappropriate processing, excess inventory, unnecessary motion as well as defects (Andrew, 2009; Vijaya Sunder, 2015). Additionally, Frank et al.(2014) in their book introduced nine waste with additional two waste : Underutilized people and employee behaviour.

\section{Overview of Six Sigma Concept}

Numerous businesses around the globe adopt Six Sigma as an initiative to helped company drive out billions of dollars in cost and driven productivity to higher level as the savings generated by six sigmas marked a positive impact towards the bottom line of the organizations' performance. Six Sigma was developed by a Motorola Senior Engineer named Bill Smith in the mid of 1980s and become popular in United State after winning the 1988 Baldrige National Quality Award (Frank et al., 2014; Snee, 2010). As a quality improvement method, Six Sigma is a statistical process measurement symbolized by the Greek letter sigma " $\sigma$ ". This $\sigma$ represents the variation amount of data distribution which also called as standard deviation (Aboelmaged, 2010; Pacheco, Pergher, Vaccaro, Jung, \& Ten Caten, 2015).

Since early eighties, Six Sigma from Motorola has evolved from solely a statistical term into an established methodology that has spread to other companies which providing businesses with a comprehensive toolset to improve the capability of business processes, process improvement, and quality of products and services in order to satisfied customer needs (Aboelmaged, 2010; Chakraborty \& Leyer, 2013; Forrest, James, \& Becki, 2001; Penelope, 2006). Six sigma has different interpretation, thus Chakraborty \& Leyer ( 2013) classified those interpretation into four main stream : first as a set of statistical tools with the aim of process quality improvement; second as a philosophy for operational management that can be shared beneficially by every stakeholder of a company; third as a business culture which is implemented top down and lastly as an analysis methodology using scientific methods for continuous processes.

Six sigma deals with several tools and techniques to tackle quality related problem that leads to minimizing defect and meeting customer requirement in result to improve overall performance for organization. The most used six sigma tools are Design of Experiment (DOE), Measurement System Analysis (MSA), Voice of Customer (VOC), Pareto Analysis, 
root cause analysis, process mapping, process flowchart, Gantt chart, and histogram. At the same time, organization also use six sigma techniques such as statistical process control (SPC), process capability analysis, and benchmarking process to tackle the issues. Additionally, one six sigma techniques can employ various tools, as an example SPC is a technique that utilizes control chart, histogram and root cause analysis (Aboelmaged, 2010).

\section{The Evolution of Lean Six Sigma}

Lean Six Sigma is the offspring of two most popular performance improvement methodologies which are lean methods and six sigma approach. The concept of combining lean and six sigma began in late 90s, with the aim to blend these two methodologies into one approach of getting things done faster, better, cheaper, safer and greener (Yadav \& Desai, 2016). Starting from that era, more companies are adopting Lean Six Sigma with the intention to increase process performance resulting in enhanced customer satisfaction and improved bottom line result (Snee, 2010). Lean Six Sigma is the result of evolution from quality and productivity, which then revolve into six sigma and lean concept (Sandra, 2009b). Figure 1 shows the evolution of this combined method.

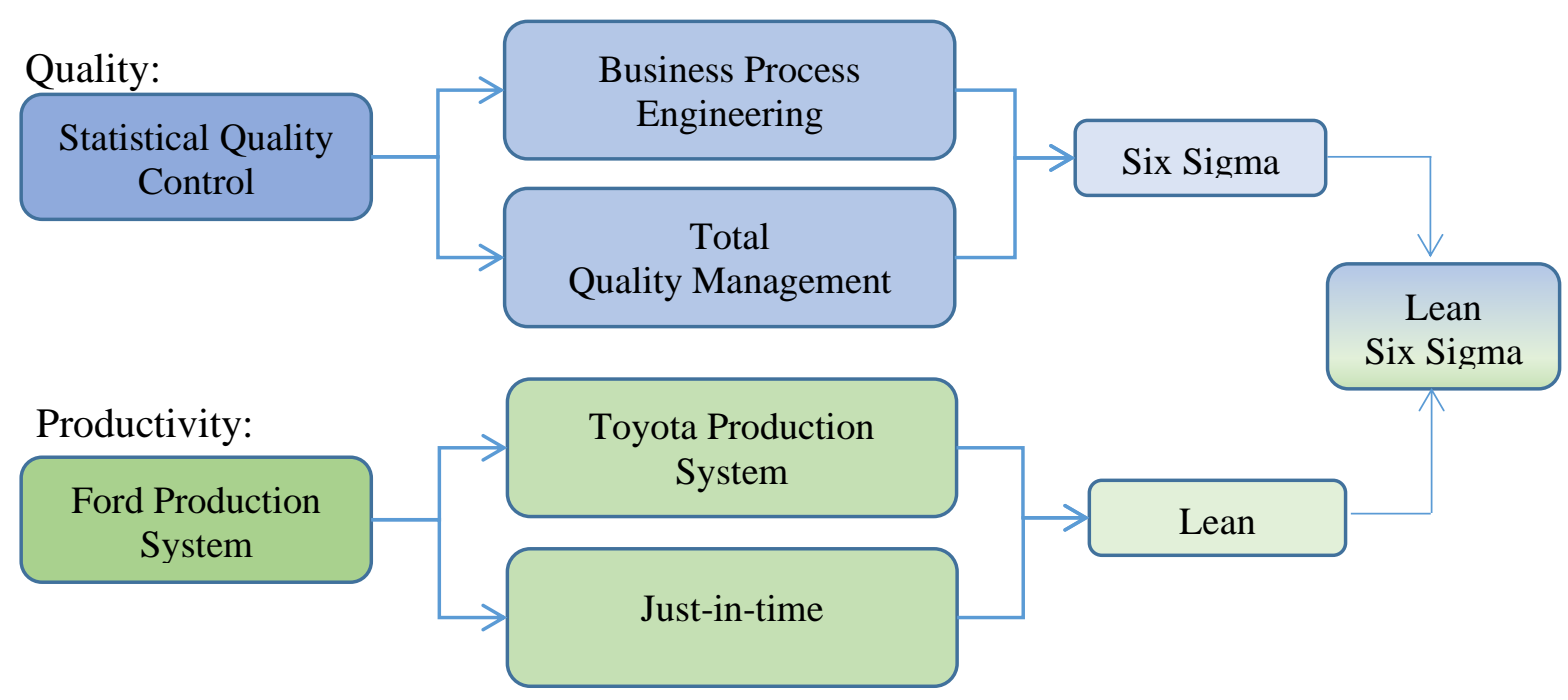

Figure 1 : Evolution of Quality and Productivity to Lean Six Sigma (Sandra, 2009b)

From a business perspective, Lean Six Sigma could be defined as a combination process that allows companies to drastically identify the customer needs, eliminate all non-value-added activities and reduce the variability within the production process (Chaurasia, Garg, \& Agarwal, 2016; Yadav \& Desai, 2016). Thus, Lean Six Sigma is needed because organizations and individuals need a methodology for improvement and problem solving (Snee, 2010). In order to choose the appropriate method, organization has to identify the nature of improvement at the first place, so that the action taken can solve the problem accordingly. In fact, not all improvement projects need Lean Six Sigma as a whole, because certain improvement projects need Six Sigma alone, while other projects need Lean Methods alone. However, based on Aboelmaged, (2010) and Gremyr \& Fouquet (2012), this two dominant method are complement to each other and become a powerful framework for eliminating process waste and variation when used together rather than used alone. Thus, organization need to have a clear direction on the purpose of every single improvement 
project that they want to carried out. Figure 2 shows how Lean and Six Sigma approaches can be used to deal with waste reduction, non-value added work \& cycle time.

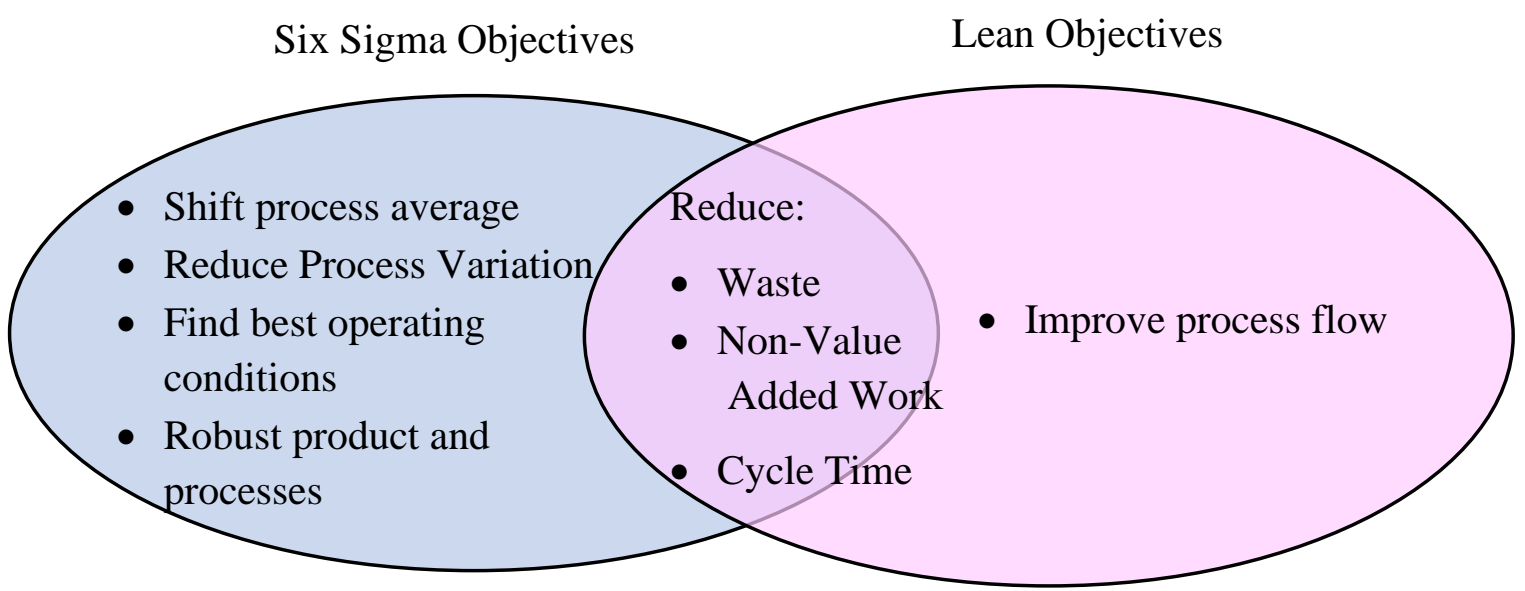

Figure 2 : Improvement Objective (Snee, 2010)

Based on the figure above it clearly shows that Lean and Six Sigma works differently, but there is a commonality between those two. Again, a standard methodology is required to integrate this Lean Six Sigma paradigm into organization.

\section{Lean Six Sigma Tools and Technique}

As the combination of Lean and Six Sigma is associated to continuous improvement, Pacheco et al (2015) suggested that lean improvement project can be manage by using DMAIC methodology. DMAIC is a disciplined, and systematic improvement approach which emphasizes on rapid project completion (Snee, 2010). In fact, Chaurasia, Garg, \& Agarwal (2016) in their research also conclude that DMAIC is one of the most influential methodologies for Lean Six Sigma. DMAIC which stand for Define, Measure, Analyze, Improve and Control are often used as a process improvement tools for projects that aims to improve existing products, processes or services (Frank et al., 2014; S.Thomas \& Kunal, 2013a; Sandra, 2009b). As DMAIC is a structured process improvement methodology, it combines with a well-defined set of tools that are applied at various phases of the DMAIC (Shafer \& Moeller, 2012).

In the first place, DMAIC is actually a modification of the PDCA (Plan-Do-Check-Action) cycle which are originally introduced by William Edward Deming, but with additional tools and methods, DMAIC has been used for many improvement projects which vary from different discipline and industry (Andersson, Hilletofth, \& Manfredsson, 2014; Pacheco et al., 2015). For instance, DMAIC has been used for improvement project in medical (Toledo H. et al., 2013), financial (Sandra, 2009a), logistic (Blake, Stefan, Parker, Matt, \& Sandra, 2009), inventory and asset management (Felix et al., 2009), shop floor production (Kumar \& Sosnoski, 2009), automotive (Vikas \& S. Vinodh, 2016), Telecom Production (Andersson, Hilletofth, \& Manfredsson, 2014), Oil Production (Chaurasia et al., 2016) as well as in higher education (Marcela, Khalid, Kevin, Jose, \& Sandra, 2009; Vijaya Sunder, 2016)

From those examples, it shows that DMAIC seems to be one of the most value aspects of improvements tools for any organization from various industries either for major or minor project. At such, Assarlind, Gremyr, \& Bäckman (2013) describe that extensive stage-gate 
DMAIC cycles are utilized for large projects, while the simplified versions are used for smaller everyday improvement activities.

Firstly, DMAIC allows organization to identify a problem (Define), and then convert it into statistical problem (Measure), after that discuss and verify the cause of the problem and suspected root cause (Analyze), continue with action identification (Improve) and finally apply a practical solution (Control). Unfortunately, from the review it found out that there is no consistency of tools used throughout the DMAIC phased as there are tools that used repeatedly and few are redundant.

\section{Define - What is important?}

Define phase is the initial phase for lean six sigma project. Certainly, this phase is to identify and validate the opportunity where improvement can have a significant impact to the organization (Thomas, Francis, Fisher, \& Byard, 2016; Vikas \& S. Vinodh, 2016).

Table 1: Details tools for Define Phase

\begin{tabular}{|c|c|c|c|c|c|c|c|c|c|c|c|c|}
\hline \multirow[b]{2}{*}{ Authors / Year } & \multirow[b]{2}{*}{ Industry } & \multicolumn{11}{|c|}{ Specific Tools Used [Define Phase] } \\
\hline & & 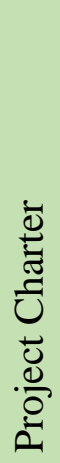 & 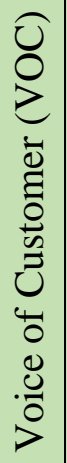 & 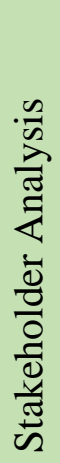 & 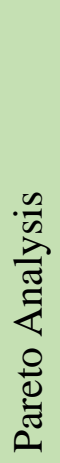 & 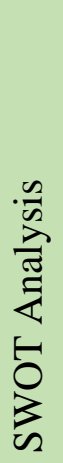 & 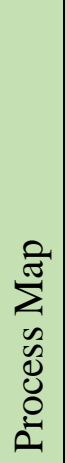 & 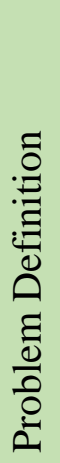 & 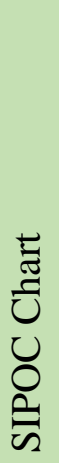 & 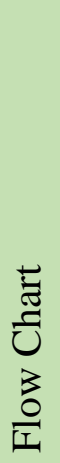 & 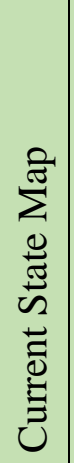 & 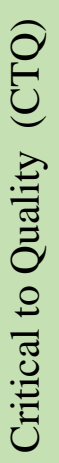 \\
\hline $\begin{array}{l}\text { Vijaya Sunder, } \\
2016\end{array}$ & Education & $\mathrm{X}$ & & & & & $\mathrm{X}$ & & & & & \\
\hline $\begin{array}{l}\text { Chaurasia et al., } \\
2016\end{array}$ & Oil Production & & & & & & $\mathrm{X}$ & $\mathrm{X}$ & & & & \\
\hline $\begin{array}{l}\text { Vikas \& S. Vinodh, } \\
2016\end{array}$ & $\begin{array}{l}\text { Automotive } \\
\text { Component } \\
\text { Production }\end{array}$ & $X$ & & & & & & $\mathrm{X}$ & $\mathrm{X}$ & $\mathrm{X}$ & $X$ & \\
\hline $\begin{array}{l}\text { Andersson, } \\
\text { Hilletofth, \& } \\
\text { Manfredsson, } 2014\end{array}$ & $\begin{array}{l}\text { Telecom } \\
\text { Manufacturing }\end{array}$ & & $X$ & & & $\mathrm{X}$ & $\mathrm{X}$ & $\mathrm{X}$ & $\mathrm{X}$ & & & $\mathrm{X}$ \\
\hline $\begin{array}{l}\text { Toledo H. et al., } \\
2013\end{array}$ & Medical & $\mathrm{X}$ & & $X$ & & & & & & & & \\
\hline $\begin{array}{l}\text { Kumar \& Sosnoski, } \\
2009\end{array}$ & $\begin{array}{l}\text { Shop floor } \\
\text { production }\end{array}$ & $\mathrm{X}$ & & & $\mathrm{X}$ & & & & & & & \\
\hline
\end{tabular}

\section{Measure - How are We Doing?}

Basically Measure phase is where researcher identify the potential root cause of certain problems, and investigate how this root cause might affect the overall process and how to measure them (Andersson et al., 2014). Equally important, from this phase a quantitative problem statement will be developed based on the measurable data that have been collected earlier (Frank et al., 2014). 
In Measure phase, the tools used is differed depends on the type of industry and type of process improvement as per shown in table 2. Overall, there is not much similarity of tools used in measure phase.

Table 2: Details tools for Measure Phase

\begin{tabular}{|c|c|c|c|c|c|c|c|c|}
\hline \multirow[b]{2}{*}{ Authors / Year } & \multirow[b]{2}{*}{ Industry } & \multicolumn{7}{|c|}{ Specific Tools Used [Measure Phase] } \\
\hline & & 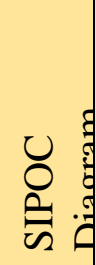 & $\begin{array}{c}3 \\
0 \\
\frac{0}{I I} \\
w \\
0 \\
0 \\
0 \\
0 \\
0 \\
0\end{array}$ & 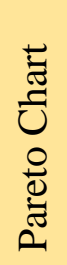 & 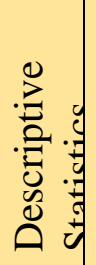 & 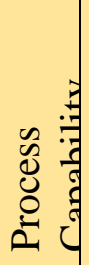 & 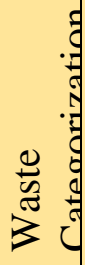 & 悬 \\
\hline Vijaya Sunder, 2016 & Education & & & & $\mathrm{X}$ & & & \\
\hline Chaurasia et al., 2016 & Oil Production & $\mathrm{X}$ & & & & & & \\
\hline $\begin{array}{l}\text { Vikas \& S. Vinodh, } \\
2016\end{array}$ & $\begin{array}{l}\text { Automotive Component } \\
\text { Production }\end{array}$ & & & & & $X$ & $\mathrm{X}$ & \\
\hline $\begin{array}{l}\text { Andersson, Hilletofth, } \\
\& \text { Manfredsson, } 2014\end{array}$ & Telecom Manufacturing & & & & & & & $\mathrm{X}$ \\
\hline Toledo H. et al., 2013 & Medical & & $\mathrm{X}$ & & $\mathrm{X}$ & & & \\
\hline $\begin{array}{l}\text { Kumar \& Sosnoski, } \\
2009\end{array}$ & Shop floor production & & & $X$ & $X$ & $X$ & & \\
\hline
\end{tabular}

\section{Analyze - What is Wrong?}

The third phase in DMAIC methodology is Analyze. In this phase, researcher used the data collected from the Measure phase which are the root causes to document the current performance and check on the factors that need improvement (Andersson et al., 2014; Andrew, 2009; S.Thomas \& Kunal, 2013a). Analyze involve gathering and analyzing cause and effect relationship, then validate the root causes and finally develop the process capability.

Table 3 shows that in most industry, researcher tends to use Cause and Effect Diagram in Analyze phase. Cause and Effect Diagram also known as fishbone diagram or Ishikawa Diagram is one of the powerful tools to helps researcher findings the lower level of variation in order to solve the problem (S.Thomas \& Kunal, 2013b). Since various root cause is already identified in previous phase, thus it is important for researcher to understand the sources of this variation, so that the problem can be solved quickly and effectively (Frank et al., 2014). 
Table 3: Details tools for Analyze Phase

\begin{tabular}{|c|c|c|c|c|c|c|c|c|c|}
\hline \multirow[b]{2}{*}{ Authors / Year } & \multirow[b]{2}{*}{ Industry } & \multicolumn{8}{|c|}{ Specific Tools Used [Analyze Phase] } \\
\hline & & 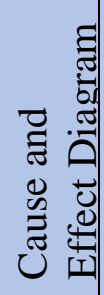 & 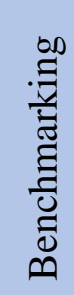 & 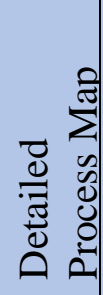 & 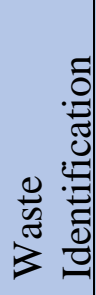 & 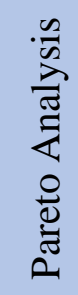 & 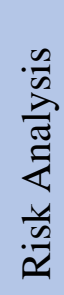 & $\sum_{n}^{\vec{B}}$ & 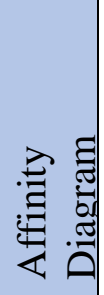 \\
\hline Vijaya Sunder, 2016 & Education & $\mathrm{X}$ & & & $\mathrm{X}$ & & & & \\
\hline $\begin{array}{l}\text { Chaurasia et al., } \\
2016\end{array}$ & Oil Production & $X$ & & & & $\mathrm{X}$ & & & \\
\hline $\begin{array}{l}\text { Vikas \& S. Vinodh, } \\
2016\end{array}$ & $\begin{array}{l}\text { Automotive Component } \\
\text { Production }\end{array}$ & $X$ & & & & $X$ & & & \\
\hline $\begin{array}{l}\text { Andersson, } \\
\text { Hilletofth, \& } \\
\text { Manfredsson, } 2014\end{array}$ & Telecom Manufacturing & & & & & & $X$ & & \\
\hline $\begin{array}{l}\text { Toledo H. et al., } \\
2013\end{array}$ & Medical & $\mathrm{X}$ & $\mathrm{X}$ & $\mathrm{X}$ & & & & $\mathrm{X}$ & $\mathrm{X}$ \\
\hline $\begin{array}{l}\text { Kumar \& Sosnoski, } \\
2009\end{array}$ & Shop floor production & $X$ & & $X$ & & & & & \\
\hline
\end{tabular}

\section{Improve - What Need to Be Done?}

Different scholar interprets Improve Phase differently. Andersson et al., (2014) classify it as a process robust, S.Thomas \& Kunal, (2013a) referred it as offline experimentation while Frank et al., (2014) called it as system improvement. After all, all this scholars agreed that the purpose of Improve Phase is to eliminate the root cause while identify improvement recommendations (Andrew, 2009; Sandra, 2009b). Improve phase involve activities such as identifying improvement recommendation, perform cost/benefit analysis, design future state, establish performance targets and project scorecard, followed by request permission for improvement implementation.

As improve phase is looking for recommendation of improvement, most industry focus on Kaizen and New Process as their approach. Initially Kaizen was developed by the Japanese to overcome the quality issues in manufacturing goods, and this concept then adopted by westerners. Kaizen comes from the term "Kai" which means change while term "Zen" means good, together they stand for continuous improvement (Raisinghani, Ette, Pierce, Cannon, \& Daripaly, 2005). Again, as kaizen is a constant and ongoing improvement activity, it manage to create a culture of continuous improvement in organization (Sisson \& Elshennawy, 2015). Additionally, Snee (2010) classified Kaizen as a rapid improvement project which typically completed in 30 days or less. Table 4 below show the details tools used for improving phase in different industry. 
Table 4: Details Tools for Improve Phase

\begin{tabular}{|c|c|c|c|c|c|c|c|c|c|c|}
\hline \multirow[b]{2}{*}{ Authors / Year } & \multirow[b]{2}{*}{ Industry } & \multicolumn{9}{|c|}{ Specific Tools Used [Improve Phase] } \\
\hline & & 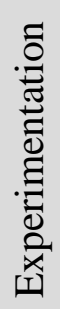 & 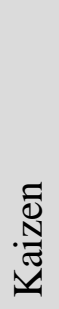 & 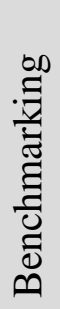 & 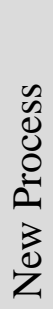 & 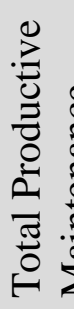 & 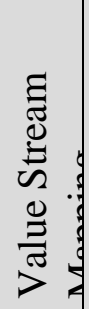 & 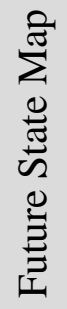 & 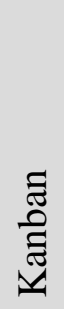 & 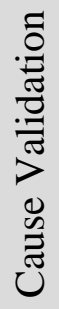 \\
\hline $\begin{array}{l}\text { Vijaya Sunder, } \\
2016\end{array}$ & Education & & & $\mathrm{X}$ & $\mathrm{X}$ & & & & & \\
\hline $\begin{array}{l}\text { Chaurasia et al., } \\
2016\end{array}$ & Oil Production & & $\mathrm{X}$ & & & $X$ & $\mathrm{X}$ & & $\mathrm{X}$ & \\
\hline $\begin{array}{l}\text { Vikas \& S. Vinodh, } \\
2016\end{array}$ & $\begin{array}{l}\text { Automotive } \\
\text { Component } \\
\text { Production }\end{array}$ & & & & & & & $\mathrm{X}$ & & $\mathrm{X}$ \\
\hline $\begin{array}{l}\text { Andersson, } \\
\text { Hilletofth, \& } \\
\text { Manfredsson, } 2014\end{array}$ & $\begin{array}{l}\text { Telecom } \\
\text { Manufacturing }\end{array}$ & & $\mathrm{X}$ & & & $\mathrm{X}$ & & & & \\
\hline $\begin{array}{l}\text { Toledo H. et al., } \\
2013\end{array}$ & Medical & & & & $\mathrm{X}$ & & & & & \\
\hline $\begin{array}{l}\text { Kumar \& Sosnoski, } \\
2009\end{array}$ & $\begin{array}{l}\text { Shop floor } \\
\text { production }\end{array}$ & $\mathrm{X}$ & & & $\mathrm{X}$ & & & & & \\
\hline
\end{tabular}

\section{Control - How we Guarantee Performance?}

Control is the very last phase of DMAIC. In control phase, researcher will decide either the solution of improvement project is proven to success or vice versa (Andersson et al., 2014). Thus, it is crucial to record down every single possible implementation which done in improve phase so that this improvement can be documented (Vikas \& S. Vinodh, 2016). Through control phase, researcher will develop and validate a monitoring and control system which taking care of sustaining improvements and represents the implementation in a full scale (Ali, Islam, \& Howe, 2013; Vijaya Sunder, 2015; Yahia, 2011).

Control phase involve activities such measuring results and managing changes, continue with reporting scorecard data and creating process control plan, then followed by applying PDCA cycle and finally develop a future plan. From table 5 below, it show that in most industry researcher tend to use Control Chart and Sustainability Plan in Control phase. Control chart is a statistical process control tools which indicates the variation of the process and intensity of defects occurrence (Vikas \& S. Vinodh, 2016). 
Table 5: Details tools for Control Phase

\begin{tabular}{|c|c|c|c|c|c|c|c|}
\hline \multirow[b]{2}{*}{ Authors / Year } & \multirow[b]{2}{*}{ Industry } & \multicolumn{6}{|c|}{ Specific Tools Used [Control Phase] } \\
\hline & & 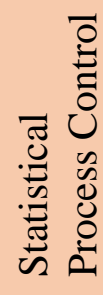 & 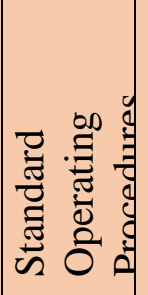 & 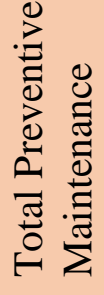 & 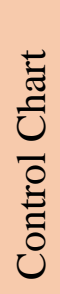 & 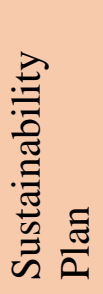 & 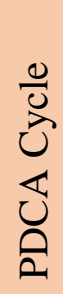 \\
\hline $\begin{array}{l}\text { Vijaya Sunder, } \\
2016\end{array}$ & Education & & X & & $\mathrm{X}$ & & \\
\hline $\begin{array}{l}\text { Chaurasia et al., } \\
2016\end{array}$ & Oil Production & & $X$ & & $\mathrm{X}$ & $X$ & \\
\hline $\begin{array}{l}\text { Vikas \& S. } \\
\text { Vinodh, } 2016\end{array}$ & $\begin{array}{l}\text { Automotive } \\
\text { Component } \\
\text { Production } \\
\end{array}$ & & & & $X$ & $X$ & \\
\hline $\begin{array}{l}\text { Andersson, } \\
\text { Hilletofth, \& } \\
\text { Manfredsson, } 2014\end{array}$ & $\begin{array}{l}\text { Telecom } \\
\text { Manufacturing }\end{array}$ & & & $X$ & & & $\mathrm{X}$ \\
\hline $\begin{array}{l}\text { Toledo H. et al., } \\
2013\end{array}$ & Medical & & & & & $X$ & \\
\hline $\begin{array}{l}\text { Kumar \& } \\
\text { Sosnoski, } 2009\end{array}$ & Shop floor production & $\mathrm{X}$ & & & & & \\
\hline
\end{tabular}

Based on the review from 6 industries education, oil production, automotive component production, telecom manufacturing, medical and shop floor production we could summaries that there is no single template for process improvement as the steps taken and tools used are vary. Thus, we summarise the finding in table 6 below.

Table 6: Tools Used in DMAIC Stages

\begin{tabular}{|l|c|c|c|c|c|}
\hline \multicolumn{1}{|c|}{ Tools } & D & M & A & I & C \\
\hline Project Charter & X & & & & \\
\hline Voice of Customer (VOC) & X & & & & \\
\hline Stakeholder Analysis & X & & & & \\
\hline Pareto Analysis & X & X & X & & \\
\hline SWOT Analysis & X & & & & \\
\hline Process Map & X & & & & \\
\hline Process Flow Diagram & & X & & & \\
\hline Problem Definition & $\mathrm{X}$ & & & & \\
\hline SIPOC Diagram & $\mathrm{X}$ & $\mathrm{X}$ & & & \\
\hline Flow Chart & $\mathrm{X}$ & & & & \\
\hline Current State Map & $\mathrm{X}$ & & & & \\
\hline Critical to Quality (CTQ) & $\mathrm{X}$ & & & & \\
\hline Descriptive Statistic & & $\mathrm{X}$ & & & \\
\hline Process Capability Analysis & & $\mathrm{X}$ & & & \\
\hline Waste Categorization & & $\mathrm{X}$ & & & \\
\hline Affinity Diagram & & $\mathrm{X}$ & $\mathrm{X}$ & & \\
\hline Cause and Effect Diagram & & $\mathrm{X}$ & & \\
\hline
\end{tabular}




\begin{tabular}{|c|c|c|c|}
\hline Benchmarking & $\mathrm{X}$ & $\mathrm{X}$ & \\
\hline Detailed Process Map & $\mathrm{X}$ & & \\
\hline Waste Identification & $\mathrm{X}$ & & \\
\hline Risk Analysis & $\mathrm{X}$ & & \\
\hline 5 Why & $\mathrm{X}$ & & \\
\hline Experimentation & & $\mathrm{X}$ & \\
\hline Kaizen & & $\mathrm{X}$ & \\
\hline New Process & & $\mathrm{X}$ & \\
\hline Total Productive Maintenance & & $\mathrm{X}$ & \\
\hline Value Stream Mapping & & $\mathrm{X}$ & \\
\hline Future State Map & & $\mathrm{X}$ & \\
\hline Kanban & & $\mathrm{X}$ & \\
\hline Cause Validation & & $\mathrm{X}$ & \\
\hline Statistical Process Control & & & $\mathrm{X}$ \\
\hline Standard Operating Procedure & & & $\mathrm{X}$ \\
\hline Total Preventive Maintenance & & & $\mathrm{X}$ \\
\hline Control Chart & & & $\mathrm{X}$ \\
\hline Sustainability Plan & & & $\mathrm{X}$ \\
\hline PDCA Cycle & & & $\mathrm{X}$ \\
\hline
\end{tabular}

\section{Conclusion}

Overall, this paper seeks to gather and compare the experience of various organizations from various industries undertaking DMAIC activities within their organization in order to sustain the performance and maximize organization value. Thus, this paper will give a clear picture on tools \& practices for each of DMAIC stages in the industries. The findings will generate an effective comparison to improve LSS practitioners in their present jobs, to acquire new techniques to embark new challenge, and to continuously improve their organization performance in a changing pace of technologies.

\section{References}

Aboelmaged, M. G. (2010). Six Sigma quality: a structured review and implications for future research. International Journal of Quality \& Reliability Management, 27(3), 268-317. http://doi.org/10.1108/02656711011023294

Ali, A. J., Islam, M. A., \& Howe, L. P. (2013). A study of sustainability of continuous improvement in the manufacturing industries in Malaysia: Organizational selfassessment as a mediator. Management of Environmental Quality: An International Journal, 24(3), 408-426. http://doi.org/10.1108/14777831311322695

Andersson, R., Hilletofth, P., \& Manfredsson, P. (2014). Lean Six Sigma strategy in telecom manufacturing. Industrial Management \& Data Systems, 114(6), 904-921. http://doi.org/10.1108/IMDS-02-2014-0069

Andrew, G. (2009). Operations Management (2nd Editio). West Sussex, England: John Willey \& Sons Ltd.

Assarlind, M., Gremyr, I., \& Bäckman, K. (2013). Multi-faceted views on a Lean Six Sigma application. International Journal of Quality \& Reliability Management, 30(4), $387-$ 402. http://doi.org/10.1108/02656711311308385

Blake, H., Stefan, M., Parker, R., Matt, S., \& Sandra, L. F. (2009). Industrial Distribution and Logistics (IDIS) Program Recruiting Process Design - A Lean Six Sigma Case Study. 
In Lean Six Sigma in Service: Application and Case Study (pp. 207-252). Broken Sound Parkway NW: CRC Press, Taylor \& Francis Group.

Chakraborty, A., \& Leyer, M. (2013). Developing a Six Sigma framework: perspectives from financial service companies. International Journal of Quality \& Reliability Management, 30(3), 256-279. http://doi.org/10.1108/02656711311299836

Chaurasia, B., Garg, D., \& Agarwal, A. (2016). Framework to improve performance through implementing Lean Six Sigma strategies to oil exporting countries during recession or depression. International Journal of Productivity and Performance Management, 65(3), 422-432. http://doi.org/10.1108/IJPPM-01-2015-0011

Felix, M., Varshini, G., Amol, S., Robert, B., Russ, D., Miguel, T., \& Sandra, L. F. (2009). CECS Inventory and Asset Management Process Improvement- A Lean Six Sigma Case Study. In Lean Six Sigma in Service: Application and Case Study (pp. 253-318).

Forrest, W. B., James, M. C., \& Becki, M. (2001). Managing Six Sigma : A Practical Guide to Understanding, Assessing and Implementing the Strategy that Yields Bottom-Line Success. Third Avenue, New York: John Willey \& Sons, Inc.

Frank, V., H.James, H., Chuck, M., \& Rich, C. (2014). The Lean Six Sigma Black Belt Handbook. Broken Sound Parkway NW: CRC Press, Taylor \& Francis Group.

Gremyr, I., \& Fouquet, J. (2012). Design for Six Sigma and lean product development. International Journal of Lean Six Sigma, 3(1), 45-58. http://doi.org/10.1108/20401461211223722

Kumar, S., \& Sosnoski, M. (2009). Using DMAIC Six Sigma to systematically improve shopfloor production quality and costs. International Journal of Productivity and Performance Management, $\quad$ 58(3), 254-273. http://doi.org/10.1108/17410400910938850

Marcela, B., Khalid, B., Kevin, C., Jose, S., \& Sandra, L. F. (2009). Sunshine High School Discipline Process Improvement - A Lean Six Sigma Case Study. In Lean Six Sigma in Service: Application and Case Study (pp. 73-154). Broken Sound Parkway NW: CRC Press, Taylor \& Francis Group.

Pacheco, D., Pergher, I., Vaccaro, G. L. R., Jung, C. F., \& Ten Caten, C. (2015). 18 comparative aspects between Lean and Six Sigma. International Journal of Lean Six Sigma, 6(2), 161-175. http://doi.org/10.1108/IJLSS-05-2014-0012

Penelope, P. (2006). Six Sigma for Business Excellence. New York: The McGraw Hill.

Raisinghani, M. S., Ette, H., Pierce, R., Cannon, G., \& Daripaly, P. (2005). Six Sigma: concepts, tools, and applications. Industrial Management \& Data Systems, 105(4), 491-505. http://doi.org/10.1108/02635570510592389

S.Thomas, F., \& Kunal, K. G. (2013a). Six Sigma Management and Lean Tools. In Managing Quality: Integrating the Supply Chain (5th Editio). Harlow, England: Pearson Education.

S.Thomas, F., \& Kunal, K. G. (2013b). The Tools of Quality. In Managing Quality: Integrating the Supply Chain (5th Editio, pp. 262-299). Harlow, England: Pearson Education.

Sandra, L. F. (2009a). Financial Services Improvement in City Goverment - A Lean Six Sigma Case Study. In Lean Six Sigma in Service: Application and Case Study (pp. 155-206). Broken Sound Parkway NW: CRC Press, Taylor \& Francis Group.

Sandra, L. F. (2009b). Lean Six Sigma Roadmap. In Lean Six Sigma in Service: Application and Case Study. Boca Raton, FL: Taylor \& Francis Group.

Shafer, S. M., \& Moeller, S. B. (2012). The effects of Six Sigma on corporate performance: An empirical investigation. Journal of Operations Management, 30(7-8), 521-532. http://doi.org/10.1016/j.jom.2012.10.002 
Sisson, J., \& Elshennawy, A. (2015). Achieving success with Lean. International Journal of Lean Six Sigma, 6(3), 263-280. http://doi.org/10.1108/IJLSS-07-2014-0024

Snee, R. D. (2010). Lean Six Sigma - getting better all the time. International Journal of Lean Six Sigma, 1(1), 9-29. http://doi.org/10.1108/20401461011033130

Thomas, A. J., Francis, M., Fisher, R., \& Byard, P. (2016). Implementing Lean Six Sigma to overcome the production challenges in an aerospace company. Production Planning \& Control, 7287(May), 1-13. http://doi.org/10.1080/09537287.2016.1165300

Toledo H., A., Carroll, T., Arnold, E., Tulu, Z., Caffey, T., Kearns E., L., \& Gerber A., D. (2013). Reducing liver transplant length of stay: a Lean Six Sigma approach. Progress in Transplantation, 23(4), 350-364. http://doi.org/10.7182/pit2013226

Vijaya Sunder, M. (2015). Corporate perspectives: commonalities and differences between Six Sigma and Lean. International Journal of Lean Six Sigma, 6(3), 281-288. http://doi.org/10.1108/IJLSS-12-2014-0038

Vijaya Sunder, M. (2016). Lean Six Sigma in higher education institutions. International Journal of Quality and Service Sciences, 8(2), 159-178. http://doi.org/10.1108/IJQSS04-2015-0043

Vikas, S., \& S. Vinodh. (2016). Deploying Lean Six Sigma framework in an automotive component manufacturing organization. International Journal of Lean Six Sigma, 7(3), 267-293. http://doi.org/10.1108/IJLSS-06-2015-0023

Yadav, G., \& Desai, T. N. (2016). Lean Six Sigma: a categorized review of the literature. International Journal of Lean Six Sigma, 7(1), 2-24. http://doi.org/10.1108/IJLSS-052015-0015

Yahia, Z. M. (2011). Six-Sigma: methodology, tools and its future. Assembly Automation, 31(1), 79-88. http://doi.org/10.1108/01445151111104209 